\title{
Zobellia amurskyensis sp. nov., Zobellia laminariae sp. nov. and Zobellia russellii sp. nov., novel marine bacteria of the family Flavobacteriaceae
}

\author{
Correspondence \\ Olga I. Nedashkovskaya \\ olganedashkovska@yahoo.com
}

\author{
Olga I. Nedashkovskaya, ${ }^{1}$ Makoto Suzuki, ${ }^{2}$ Marc Vancanneyt, ${ }^{3}$ \\ Ilse Cleenwerck, ${ }^{3}$ Anatoly M. Lysenko, ${ }^{4}$ Valery V. Mikhailov ${ }^{1}$ \\ and Jean Swings ${ }^{3}$
}

\begin{abstract}
${ }^{1}$ Pacific Institute of Bioorganic Chemistry of the Far-Eastern Branch of the Russian Academy of Sciences, Prospekt 100 let Vladivostoku 159, 690022, Vladivostok, Russia

${ }^{2}$ Tokyo Research Laboratories, Kyowa Hakko Kogyo Co., Ltd, 3-6-6 Asahi-machi, Machida-shi, Tokyo 194-8533, Japan

${ }^{3}$ BCCM/LMG Bacteria Collection, Laboratorium voor Microbiologie, Faculteit Wetenschappen, Ghent University, B-9000 Ghent, Belgium

${ }^{4}$ Institute of Microbiology of the Russian Academy of Sciences, Prospekt 60 let October 7/2, Moscow, 117811, Russia
\end{abstract}

\begin{abstract}
The taxonomic position of four newly isolated marine, heterotrophic, gliding, Gram-negative, aerobic, pigmented, agarolytic bacteria was established. 16S rRNA gene sequence analysis indicated affiliation of the isolates to the genus Zobellia in the family Flavobacteriaceae. DNA-DNA hybridization experiments revealed that the strains studied represent three distinct and novel species, for which the names Zobellia amurskyensis sp. nov., Zobellia laminariae sp. nov. and

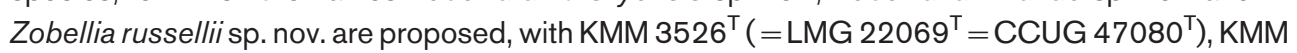
$3676^{\top}$ (= LMG $22070^{\top}=$ CCUG $\left.47083^{\top}\right)$ and KMM $3677^{\top}\left(=\right.$ LMG $22071^{\top}=$ CCUG $\left.47084^{\top}\right)$, respectively, as the type strains.
\end{abstract}

The genus Zobellia was created by Barbeyron et al. (2001) and contains Gram-negative, aerobic, gliding, agarolytic bacteria that produce flexirubin-type pigments. To date, two species of the genus Zobellia have validly published names, Zobellia galactanivorans and Zobellia uliginosa, and both originate from marine environments. The latter species was isolated from beach sand in California and was originally classified as Flavobacterium uliginosum (ZoBell \& Upham, 1944). Later, it was transferred to the genus Cytophaga as Cytophaga uliginosa (Reichenbach, 1989), reclassified in the genus Cellulophaga as Cellulophaga uliginosa (Bowman, 2000) and finally assigned to the new genus Zobellia on the basis of a higher DNA G $+\mathrm{C}$ content (mol\%), its maximum growth temperature, the presence of flexirubin pigments and its unique phylogenetic position (Barbeyron et al.,

Published online ahead of print on 5 March 2004 as DOI 10.1099/ ijs.0.63091-0.

\section{Abbreviation: CM-cellulose, carboxymethylcellulose.}

The GenBank/EMBL/DDBJ accession numbers for the 16S rRNA gene sequences of Zobellia amurskyensis KMM 3526 ${ }^{\top}$, Zobellia laminariae $\mathrm{KMM} 3676^{\top}$ and Zobellia russellii $\mathrm{KMM} 3677^{\top}$ are AB121974, AB121975 and AB121976, respectively.
2001). Z. galactanivorans, a marine species isolated from a red alga, was chosen as the type species.

In the course of a study on 450 strains isolated from sea water and bottom sediment samples, the sea urchin Strongulocentrothus intermedius and red (Polysiphonia japonica), green (Acrosiphonia sonderi and Ulva fenestrata) and brown (Chorda filum and Laminaria japonica) algae, the taxonomic position of four isolates was unclear and was further investigated in the present study. We report the results of phenotypic, physiological and genomic analyses on the latter strains, which led to the description of three novel species of the genus Zobellia, for which the names Zobellia amurskyensis sp. nov., Zobellia laminariae sp. nov. and Zobellia russellii sp. nov. are proposed.

The isolates investigated in this study were obtained during sampling in the Gulf of Peter the Great, Sea of Japan, Pacific Ocean, in June 2000. Strain KMM $3526^{\mathrm{T}}$ was isolated from a sea-water sample collected in Amursky Bay. Strains KMM $3676^{\mathrm{T}}$, KMM 3926 and KMM $3677^{\mathrm{T}}$ were recovered from the brown alga L. japonica (KMM $3676^{\mathrm{T}}$, KMM 3926) and the green alga A. sonderi $\left(\mathrm{KMM} 3677^{\mathrm{T}}\right)$, collected in Troitsa Bay. For the isolation, $0 \cdot 1 \mathrm{ml}$ sea water or algal tissue homogenates was transferred to marine agar 2216 (Difco). 
After primary isolation and purification, strains were cultivated at $28{ }^{\circ} \mathrm{C}$ on the same medium and stored at $-80^{\circ} \mathrm{C}$ in marine broth (Difco) supplemented with $20 \%$ (v/v) glycerol.

The almost complete 16S rRNA gene sequences of isolates KMM $3526^{\mathrm{T}}$, KMM $3676^{\mathrm{T}}$ and $\mathrm{KMM} 3677^{\mathrm{T}}$ were determined by PCR amplification and direct sequencing (Hiraishi, 1992). The conditions and reagents used for PCR amplification and sequencing of 16S rRNA gene were as described previously (Suzuki et al., 2001). The sequences were aligned on the secondary-structure model, maintained by the SSU rRNA database (Van de Peer et al., 2000), using the profile-alignment program of the CLUSTAL $\mathrm{W}$ software (Thompson et al., 1994). Evolutionary distances were then computed with the DNADIST program in the PHYLIP 3.572 package (Felsenstein, 1995) with the two-parameter model (Kimura, 1980); a phylogenetic tree was constructed using the neighbour-joining method (Saitou \& Nei, 1987). To evaluate the phylogenetic trees, a bootstrap analysis with 1000 sample replications was performed with the SEQBOOT and CONSENSE programs in the PHYLIP 3.572 package.

The 16S rRNA gene-based analysis revealed that KMM $3526^{\mathrm{T}}, \mathrm{KMM} 3676^{\mathrm{T}}$ and $\mathrm{KMM} 3677^{\mathrm{T}}$ formed a coherent cluster within the genus Zobellia of the family Flavobacteriaceae (Fig. 1). The level of $16 \mathrm{~S}$ rRNA gene sequence similarity between the KMM strains and $Z$. galactanivorans and $Z$. uliginosa ranged from $97 \cdot 4$ to $98 \cdot 3 \%$. The $16 \mathrm{~S}$ rRNA gene sequence similarities between strains KMM $3526^{\mathrm{T}}$, KMM $3676^{\mathrm{T}}$ and KMM $3677^{\mathrm{T}}$ ranged from $98 \cdot 2$ to $99 \cdot 3 \%$.

Genomic DNA was prepared from cells cultivated on marine agar (Difco) for $24-48 \mathrm{~h}$ at $25^{\circ} \mathrm{C}$ and extracted by following the DNA-extraction protocol of Pitcher et al. (1989), as modified by Leisner et al. (2002). DNA-DNA hybridizations were performed using the microplate method as described by Ezaki et al. (1989). Hybridizations were performed at $37^{\circ} \mathrm{C}$ in a hybridization mixture containing $50 \%$ formamide $(2 \times$ SSC, $5 \times$ Denhardt's solution, $2.5 \%$ dextran sulphate, $50 \%$ formamide, $100 \mu \mathrm{g}$ denaturated salmon sperm DNA ml ${ }^{-1}$ and $1250 \mathrm{ng}$ biotinylated probe DNA $\left.\mathrm{ml}^{-1}\right)$. The DNA G $+\mathrm{C}$ content was determined using two methods: (i) the HPLC method of Mesbah et al. (1989) on DNA extracted as indicated above and (ii) the thermal denaturation method of Marmur \& Doty (1962) on DNA extracted according to the protocol of Marmur (1961).

The $\mathrm{G}+\mathrm{C}$ contents of the DNA of strains KMM $3526^{\mathrm{T}}$, KMM $3676^{\mathrm{T}}$ and $\mathrm{KMM} 3677^{\mathrm{T}}$ were $37 \cdot 1,36 \cdot 1$ and $38.6 \mathrm{~mol} \%$, respectively, when determined by the thermal denaturation method. Slightly higher values were observed when determined by HPLC: $37 \cdot 7 \mathrm{~mol} \%$ for KMM $3526^{\mathrm{T}}$, $36.3 \mathrm{~mol} \%$ for $\mathrm{KMM} 3676^{\mathrm{T}}$ and $38.8 \mathrm{~mol} \%$ for $\mathrm{KMM}$ $3677^{\mathrm{T}}$. DNA-DNA relatedness between strains KMM $3526^{\mathrm{T}}$, KMM $3676^{\mathrm{T}}$ and $\mathrm{KMM} 3677^{\mathrm{T}}$ and the type strains $Z$. galactanivorans Dsij ${ }^{\mathrm{T}}$ and Z. uliginosa CIP $104808^{\mathrm{T}}$ ranged from 8 to $29 \%$. The DNA-DNA binding value for strains KMM $3676^{\mathrm{T}}$ and KMM 3926 was $93 \%$.

To obtain whole-cell fatty acid profiles, the strains studied were grown at $28^{\circ} \mathrm{C}$ for $24 \mathrm{~h}$ on marine agar 2216 (Difco). Analysis of fatty acid methyl esters was carried out according to the standard protocol of the Microbial Identification System (Microbial ID).

The dominant cellular fatty acids of the novel isolates and the type strains of $Z$. galactanivorans and $Z$. uliginosa were the straight-chain and branched-chain saturated and unsaturated fatty acids 15:0, iso- $15: 0$, iso- $15: 03-\mathrm{OH}$,

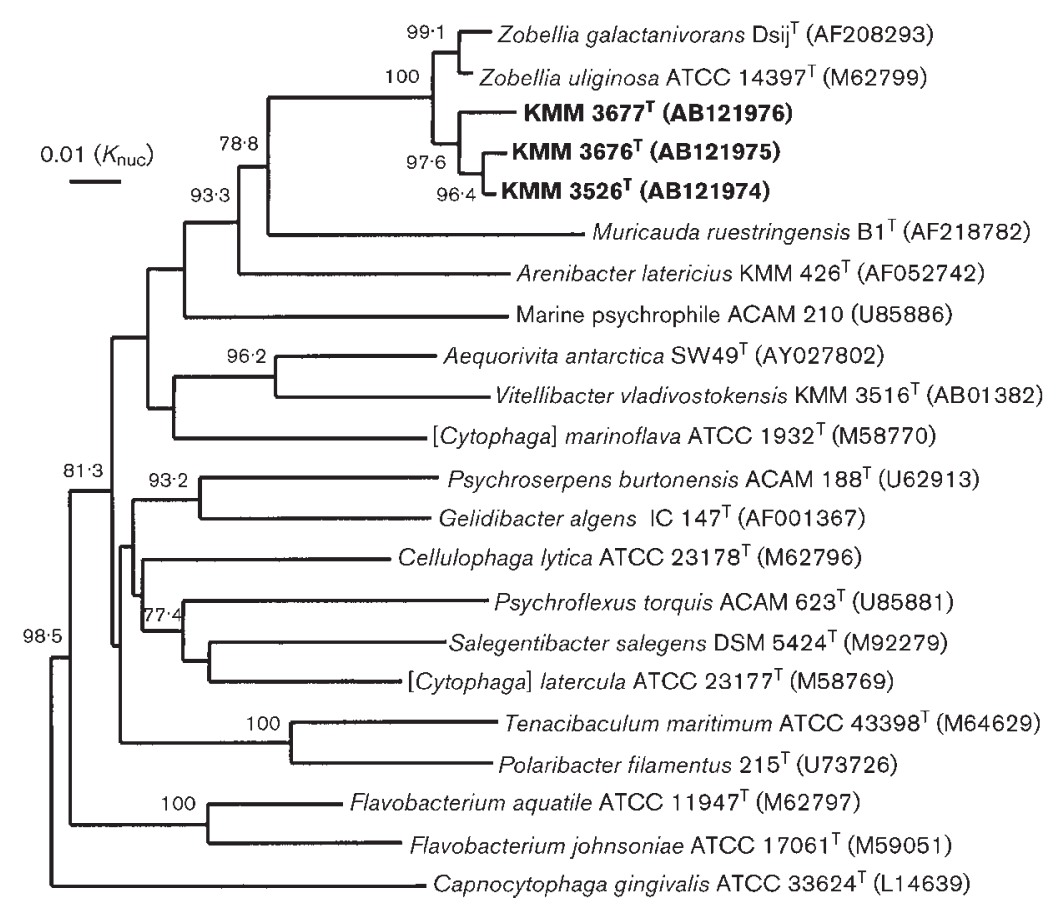

Fig. 1. Phylogenetic relationship between strains $\mathrm{KMM} 3526^{\top}, \mathrm{KMM} 3676^{\top}$ and $\mathrm{KMM}$ $3677^{\top}$ and marine species of the family Flavobacteriaceae, based on 16S rRNA gene sequence comparisons. The phylogenetic tree was generated by using the neighbour-joining method (Saitou \& Nei, 1987). The 16S rRNA gene sequence of Capnocytophaga gingivalis was used as the outgroup. The number shown next to each node indicates the percentage bootstrap value of 1000 replicates (only values of $70 \%$ or higher were cited). The scale bar indicates a genetic distance of $0.01\left(K_{\text {nuc }}\right)$. 
iso-15:1 and iso-17:0 3-OH (Table 1). No significant differences were found between the species.

Isoprenoid quinones were extracted and analysed by using the method of Nakagawa \& Yamasato (1993). The major lipoquinone of the novel isolates, $Z$. galactanivorans $\mathrm{Dsij}^{\mathrm{T}}$ and Z. uliginosa CIP $104808^{\mathrm{T}}$ was MK-6.

Gram-staining, hydrolysis of agar, starch, casein, elastin, gelatin, cellulose [filter paper and carboxymethylcellulose (CM-cellulose)], chitin, DNA, urea and alginic acids, flexirubin production, growth at different $\mathrm{pH}$ values, production of acid from carbohydrates, hydrolysis of Tweens 20, 40 and 80 , nitrate reduction, production of hydrogen sulphide and indole and $\beta$-galactosidase, oxidase, catalase and alkaline phosphatase activities were tested according to Gerhardt et al. (1994). Oxidative versus fermentative utilization of glucose was determined using Hugh \& Leifson medium modified for marine bacteria (Lemos et al., 1985). Susceptibility to antibiotics was tested as described earlier (Nedashkovskaya et al., 2003). To examine carbon-source utilization, a medium containing $0.2 \mathrm{~g} \mathrm{NaNO}_{3}, 0.2 \mathrm{~g}$ $\mathrm{NH}_{4} \mathrm{Cl}, 0.05 \mathrm{~g}$ yeast extract (Difco) and $0.4 \%(\mathrm{w} / \mathrm{v})$ carbon source in $1000 \mathrm{ml}$ artificial sea water was used. The carbon sources tested were L-arabinose, D-glucose, Dlactose, D-mannose, D-sucrose, inositol, sorbitol, mannitol, fumarate, citrate and malonate. Spreading growth was observed with cultivation on medium B containing $\left(1^{-1}\right) 1 \mathrm{~g}$
Bactopeptone (Difco), $1 \mathrm{~g}$ yeast extract (Difco), $15 \mathrm{~g}$ agar and half-strength natural sea water under high moisture conditions. Gliding motility was determined as described by Bowman (2000).

The physiological, morphological and biochemical characteristics of the strains studied are listed in the species descriptions and in Table 2. The presence of oxidase, catalase, $\beta$-galactosidase, agarase and alkaline phosphatase activities, the absence of urease activity, flexirubin-type pigment production, the reduction of nitrate to nitrite and the oxidation of carbohydrates, the absence of crystalline and amorphous cellulose hydrolysis and the respiratory quinone and fatty acid compositions of strains KMM $3526^{\mathrm{T}}$, $\mathrm{KMM} 3676^{\mathrm{T}}$ and $\mathrm{KMM} 3677^{\mathrm{T}}$ are consistent with the characteristics of $Z$. galactanivorans $\mathrm{Dsij}^{\mathrm{T}}$ and $Z$. uliginosa CIP $104808^{\mathrm{T}}$ (Table 1). However, the isolates differed clearly from $Z$. galactanivorans and $Z$. uliginosa by their inability to grow at $42^{\circ} \mathrm{C}$ and to hydrolyse casein, their ability to oxidize L-rhamnose and the lower $\mathrm{G}+\mathrm{C}$ content of their DNA (Table 2). Strain KMM $3526^{\mathrm{T}}$ is distinguished from strain KMM $3677^{\mathrm{T}}$ by the inability to grow with $8 \%$ $\mathrm{NaCl}$ or at $37^{\circ} \mathrm{C}$ or to hydrolyse Tween 40 , by the absence of acid production from L-arabinose, D-cellobiose, DL-xylose and mannitol, by susceptibility to streptomycin and by resistance to tetracycline (Table 2). It is possible to differentiate strains KMM $3526^{\mathrm{T}}$ and KMM $3676^{\mathrm{T}}$ by the hydrolysis of starch, alginate, DNA, Tweens 20,40 and 80 , by the

Table 1. Whole-cell fatty acid composition of the Zobellia species studied

Those fatty acids for which the mean amount for all taxa was less than $1 \%$ are not given. Tr, Trace amount (less than $1 \%$ ); ND, not detected.

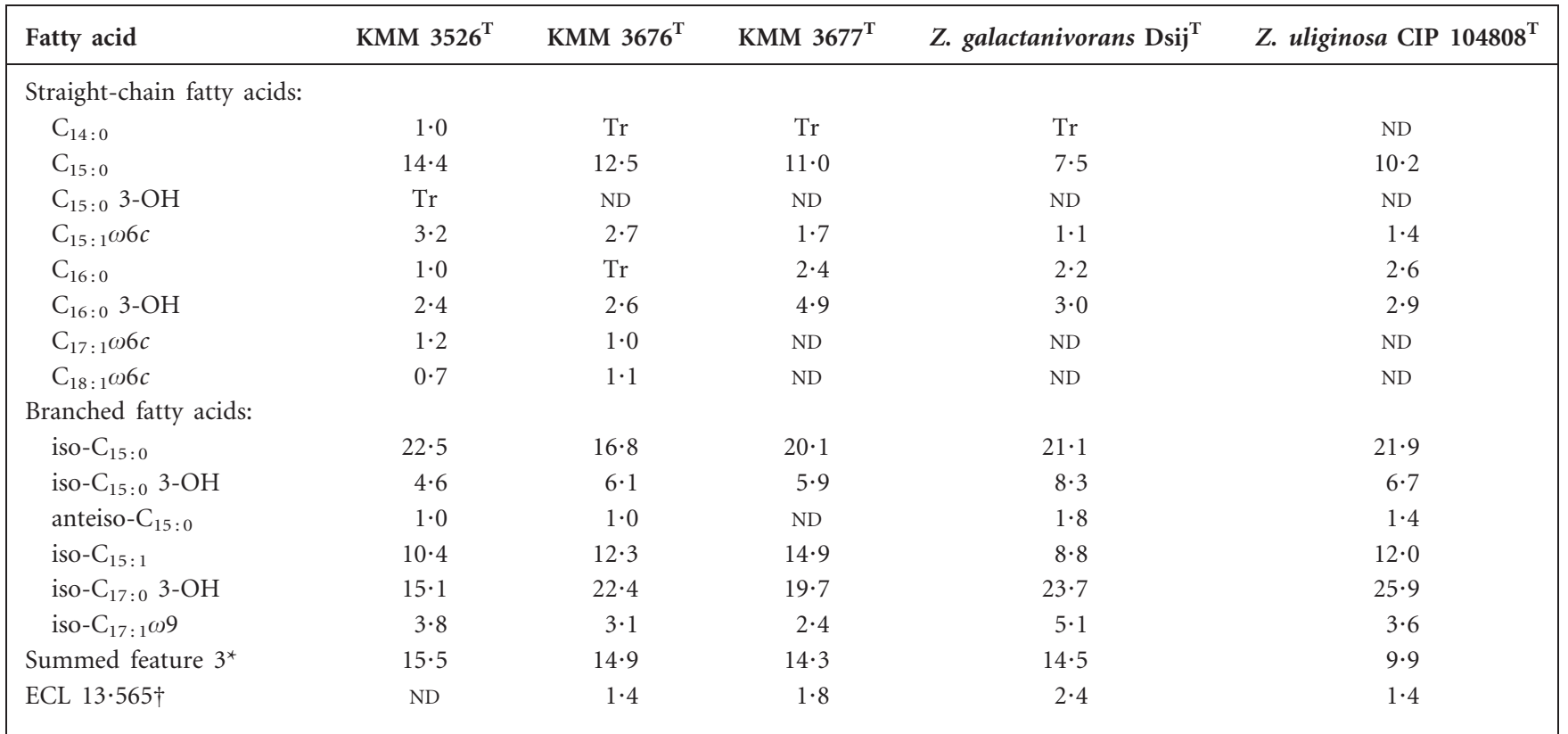

*Summed feature 3 consisted of one or more of the following fatty acids, which could not be separated by the Microbial Identification System: $\mathrm{C}_{16: 1} \omega 7 c, \mathrm{C}_{16: 1} \omega 7 t$ and iso- $\mathrm{C}_{15: 0} 2-\mathrm{OH}$.

$\dagger$ ECL, Equivalent chain-length. The identity of the fatty acid is not known. 
Table 2. Phenotypic characteristics of the Zobellia species

All strains were positive for the following: respiratory type of metabolism; movement by gliding; a requirement for $\mathrm{NaCl}$ for growth; flexirubin production; oxidase, catalase, $\beta$-galactosidase and alkaline phosphatase activities; growth at $4{ }^{\circ} \mathrm{C}$ (minimum temperature for growth of Z. galactanivorans $\mathrm{Dsij}^{\mathrm{T}}$ is $10^{\circ} \mathrm{C}$; Barbeyron et al., 2001) and with $6 \% \mathrm{NaCl}$; hydrolysis of agar and gelatin; acid formation from L-fucose; nitrate reduction; utilization of L-arabinose, D-glucose, D-lactose, D-mannose, D-sucrose and mannitol; susceptibility to carbenicillin, lincomycin and oleandomycin. All strains were negative for the following: hydrolysis of D-cellulose (CM-cellulose and filter paper), chitin and urea; production of $\mathrm{H}_{2} \mathrm{~S}$, indole and acetoin; oxidation of D-galactose, D-lactose, D-melibiose, L-sorbose, $\mathrm{N}$-acetylglucosamine, citrate, adonitol, dulcitol, glycerol and inositol; utilization of inositol, sorbitol, malonate and citrate; susceptibility to gentamicin, kanamycin, neomycin and polymixin $\mathrm{B}$.

\begin{tabular}{|c|c|c|c|c|c|}
\hline Characteristic & $\begin{array}{l}\text { Z. amurskyensis } \\
\text { KMM } 3526^{\mathrm{T}}\end{array}$ & $\begin{array}{l}\text { Z. laminariae } \\
\text { KMM } 3676^{\mathrm{T}} \text {, } \\
\text { KMM } 3926\end{array}$ & $\begin{array}{l}\text { Z. russellii } \\
\text { KMM } 3677^{\mathrm{T}}\end{array}$ & $\begin{array}{c}\text { Z. galactanivorans } \\
\mathrm{Dsij}^{\mathrm{T}}\end{array}$ & $\begin{array}{l}\text { Z. uliginosa } \\
\text { CIP } 104808^{\mathrm{T}}\end{array}$ \\
\hline $8 \% \mathrm{NaCl}$ & - & - & + & + & - \\
\hline $10 \% \mathrm{NaCl}$ & - & - & + & - & - \\
\hline $42^{\circ} \mathrm{C}$ & - & - & - & + & + \\
\hline \multicolumn{6}{|l|}{ Hydrolysis of: } \\
\hline Casein & - & - & - & + & + \\
\hline Starch & + & - & + & + & + \\
\hline Alginate & + & - & + & + & + \\
\hline \multicolumn{6}{|l|}{ Acid from: } \\
\hline L-Arabinose & - & + & + & + & - \\
\hline D-Cellobiose & - & + & + & + & - \\
\hline D-Glucose & + & + & + & - & - \\
\hline D-Maltose & + & + & + & + & - \\
\hline D-Raffinose & - & + & - & - & - \\
\hline L-Rhamnose & + & + & + & - & - \\
\hline D-Sucrose & + & + & + & - & + \\
\hline L-Xylose & - & - & + & - & - \\
\hline Mannitol & - & + & + & - & - \\
\hline \multicolumn{6}{|l|}{ Susceptibility to: } \\
\hline HPLC & $37 \cdot 7$ & $36 \cdot 3$ & $38 \cdot 8$ & $43 \cdot 0$ & $42 \cdot 9$ \\
\hline
\end{tabular}

${ }^{\star}$ Determined for the type strain.

oxidation of L-arabinose, D-cellobiose, D-raffinose and mannitol, and by susceptibility to streptomycin. KMM $3677^{\mathrm{T}}$ is distinguished from KMM $3676^{\mathrm{T}}$ by the ability to grow with $10 \% \mathrm{NaCl}$ and at $37^{\circ} \mathrm{C}$, the ability to oxidize DLxylose and the ability to hydrolyse starch, alginate, DNA, Tween 20 and Tween 80.
Phenotypic findings in combination with the differences in the phylogenetic positions, based on 16S rRNA gene sequence analysis, and the DNA-DNA relatedness between the strains studied and the existing Zobellia species, support the inclusion of strains KMM $3526^{\mathrm{T}}$, KMM $3676^{\mathrm{T}}$ and KMM $3677^{\mathrm{T}}$ in the genus Zobellia as three distinct species, for 
which the names Zobellia amurskyensis sp. nov., Zobellia laminariae sp. nov. and Zobellia russelii sp. nov are proposed.

\section{Description of Zobellia amurskyensis sp. nov.}

Zobellia amurskyensis (a.mur.sky.en'sis. N.L. fem. adj. amurskyensis of Amursky Bay, in which the type strain was isolated).

Cells range from $0 \cdot 4$ to $0.5 \mu \mathrm{m}$ in width and from $1 \cdot 2$ to $1.4 \mu \mathrm{m}$ in length. On marine agar, colonies are $2-4 \mathrm{~mm}$ in diameter, circular, shiny with entire edges, pigmented dark orange and sunken in the agar. Growth occurs at $4-32^{\circ} \mathrm{C}$, with the optimum at $23-25^{\circ} \mathrm{C}$, and at $1-6 \% \mathrm{NaCl}$, with the optimum at $2 \% \mathrm{NaCl}$. Decomposes agar, gelatin, starch, alginate, DNA, Tween 20 and Tween 80 . Does not hydrolyse casein, cellulose (CM-cellulose and filter paper), chitin or Tween 40. Forms acid from D-glucose, L-fucose, D-maltose, L-rhamnose and D-sucrose, but not from L-arabinose, Dcellobiose, D-galactose, D-lactose, D-melibiose, L-sorbose, Lraffinose, DL-xylose, $\mathrm{N}$-acetylglucosamine, citrate, adonitol, dulcitol, glycerol, inositol or mannitol. Utilizes L-arabinose, D-lactose, D-mannose and mannitol, but not inositol, sorbitol, malonate or citrate. Nitrate is reduced. $\mathrm{H}_{2} \mathrm{~S}$, indole and acetoin (Voges-Proskauer reaction) are not produced. Susceptible to carbenicillin, lincomycin, oleandomycin and streptomycin, but resistant to ampicillin, benzylpenicillin, gentamicin, kanamycin, neomycin, polymyxin $\mathrm{B}$ and tetracycline. The predominant fatty acids are $15: 0(14 \cdot 4 \%)$, i $15: 0(22 \cdot 5 \%)$, i $15: 03-\mathrm{OH}(4 \cdot 6 \%), \mathrm{i} 15: 1$ $(10 \cdot 4 \%)$ and $\mathrm{i} 17: 03-\mathrm{OH}(15 \cdot 1 \%)$. The major lipoquinone is MK-6. The $\mathrm{G}+\mathrm{C}$ content of the DNA is $37 \cdot 1 \mathrm{~mol} \%$.

The type strain is KMM $3526^{\mathrm{T}}\left(=\mathrm{LMG} 22069^{\mathrm{T}}=\mathrm{CCUG}\right.$ $\left.47080^{\mathrm{T}}\right)$. Isolated from sea water.

\section{Description of Zobellia laminariae sp. nov.}

Zobellia laminariae (la.mi.na' ri.ae. N.L. gen. n. laminariae of Laminaria, the generic name of the brown alga Laminaria japonica, from which the bacteria were isolated).

Cells range from $0 \cdot 4$ to $0.5 \mu \mathrm{m}$ in width and from 1.2 to $1.4 \mu \mathrm{m}$ in length. On marine agar, colonies are $2-4 \mathrm{~mm}$ in diameter, circular, shiny with entire edges, pigmented dark red and sunken in the agar. Growth occurs at $4-30^{\circ} \mathrm{C}$, with the optimum at $21-23{ }^{\circ} \mathrm{C}$, and at salt concentrations from 1.5 to $6 \% \mathrm{NaCl}$, with an optimum at $2 \%$. Decomposes agar, gelatin and Tween 40. Does not hydrolyse casein, starch, alginate, DNA, Tween 20, Tween 80, cellulose (CM-cellulose and filter paper) or chitin. Forms acid from L-arabinose, D-cellobiose, D-glucose, L-fucose, D-maltose, D-raffinose, L-rhamnose, D-sucrose and mannitol, but not from D-galactose, D-lactose, D-melibiose, L-sorbose, DL-xylose, $\mathrm{N}$-acetylglucosamine, citrate, adonitol, dulcitol, glycerol or inositol. Utilizes D-lactose and D-mannose, but not inositol, sorbitol, malonate or citrate. Nitrate is reduced. $\mathrm{H}_{2} \mathrm{~S}$, indole and acetoin (Voges-Proskauer reaction) are not produced. Susceptible to carbenicillin, lincomycin and oleandomycin, but resistant to ampicillin, benzylpenicillin, gentamicin, kanamycin, neomycin, polymyxin $\mathrm{B}$, streptomycin and tetracycline. The predominant fatty acids are $15: 0(12 \cdot 5 \%)$, i15:0 $(16 \cdot 8 \%)$, i15:0 $3-\mathrm{OH}(6 \cdot 1 \%)$, i15: $1(12 \cdot 3 \%)$ and i1 $17: 03-\mathrm{OH}(22 \cdot 4 \%)$. The major lipoquinone is MK-6. The $\mathrm{G}+\mathrm{C}$ content of the DNA is $36-37 \mathrm{~mol} \%$.

The type strain is KMM $3676^{\mathrm{T}}$ (=LMG $22070^{\mathrm{T}}=$ CCUG $\left.47083^{\mathrm{T}}\right)$. Isolated from the brown alga Laminaria japonica.

\section{Description of Zobellia russellii sp. nov.}

Zobellia russellii (rus'sel.li.i. N.L. gen. n. russellii of H. L. Russell, the American scientist, for his contribution to the development of marine microbiology).

Cells range from $0 \cdot 4-0 \cdot 5 \mu \mathrm{m}$ in width and from 1.2 to $1.4 \mu \mathrm{m}$ in length. On marine agar, colonies are $2-4 \mathrm{~mm}$ in diameter, circular, shiny with entire edges, pigmented dark orange and sunken in the agar. Growth occurs at $4-38{ }^{\circ} \mathrm{C}$, with the optimum at $25-28{ }^{\circ} \mathrm{C}$, and at salt concentrations between 1 and $10 \% \mathrm{NaCl}$, with the optimum at 2-3\%. Decomposes agar, gelatin, starch, alginate, DNA, Tween 20, Tween 40 and Tween 80. Does not hydrolyse casein, cellulose (CM-cellulose and filter paper) or chitin. Forms acid from L-arabinose, D-cellobiose, D-glucose, L-fucose, Dmaltose, L-rhamnose, D-sucrose, DL-xylose and mannitol, but not from D-galactose, D-lactose, D-melibiose, L-sorbose, D-raffinose, $\mathrm{N}$-acetylglucosamine, citrate, adonitol, dulcitol, glycerol or inositol. Utilizes D-lactose and D-mannose, but not inositol, sorbitol, malonate or citrate. Nitrate is reduced. $\mathrm{H}_{2} \mathrm{~S}$, indole and acetoin (Voges-Proskauer reaction) are not produced. Susceptible to carbenicillin, lincomycin, oleandomycin and tetracycline, but resistant to ampicillin, benzylpenicillin, gentamicin, kanamycin, neomycin, polymyxin $B$ and streptomycin. The predominant fatty acids are $15: 0(11 \cdot 0 \%)$, i15:0 (20.1\%), i15:0 3-OH (5.9\%), i15: 1 $(14 \cdot 9 \%)$ and i $17: 03-\mathrm{OH}(19 \cdot 7 \%)$. The major lipoquinone is MK-6. The $\mathrm{G}+\mathrm{C}$ content of the DNA is $38.6 \mathrm{~mol} \%$.

The type strain is KMM $3677^{\mathrm{T}}\left(=\mathrm{LMG} 22071^{\mathrm{T}}=\mathrm{CCUG}\right.$ $\left.47084^{\mathrm{T}}\right)$. Isolated from the green alga Acrosiphonia sonderi.

\section{Acknowledgements}

We are grateful to Dr T. Barbeyron (Station Biologique de Roscoff, France) and Dr C. Bizet (Collection de Bacteries de l'Institute Pasteur, France) for providing us with the type strains $Z$. galactanivorans Dsij ${ }^{\mathrm{T}}$ and Z. uliginosa CIP $104808^{\mathrm{T}}$, respectively, used in this study. This research was supported by grants from the Ministry for Industry, Science and Technologies of the Russian Federation (2-2.16), the Russian Foundation for Basic Research (02-04-49517) and the FarEastern Branch and Presidium of the Russian Academy of Sciences (03-1-0-05-005).

\section{References}

Barbeyron, T., L'Haridon, S., Corre, E., Kloareg, B. \& Potin, P. (2001). Zobellia galactanovorans gen. nov., sp. nov., a marine species of Flavobacteriaceae isolated from a red alga, and classification of 
[Cytophaga] uliginosa (ZoBell and Upham 1944) Reichenbach 1989 as Zobellia uliginosa gen. nov., comb. nov. Int J Syst Evol Microbiol 51, 985-997.

Bowman, J. P. (2000). Description of Cellulophaga algicola sp. nov., isolated from the surfaces of Antarctic algae, and reclassification of Cytophaga uliginosa (ZoBell and Upham 1944) Reichenbach 1989 as Cellulophaga uliginosa comb. nov. Int J Syst Evol Microbiol 50, 1861-1868.

Ezaki, T., Hashimoto, Y. \& Yabuuchi, E. (1989). Fluorometric deoxyribonucleic acid-deoxyribonucleic acid hybridization in microdilution wells as an alternative to membrane filter hybridization in which radioisotopes are used to determine genetic relatedness among bacterial strains. Int J Syst Bacteriol 39, 224-229.

Felsenstein, F. (1995). PHYLIP (Phylogeny Inference Package) version 3.57c. Seattle: University of Washington.

Gerhardt, P., Murray, R. G. E., Wood, W. A. \& Krieg, N. R. (editors) (1994). Methods for General and Molecular Bacteriology. Washington, DC: American Society for Microbiology.

Hiraishi, A. (1992). Direct automated sequencing of $16 \mathrm{~S}$ rDNA amplified by polymerase chain reaction from bacterial cultures without DNA purification. Lett Appl Microbiol 15, 210-213.

Kimura, M. (1980). A simple method for estimating evolutionary rates of base substitutions through comparative studies of nucleotide sequences. J Mol Evol 16, 111-120.

Leisner, J. J., Vancanneyt, M., Lefebvre, K., Vandemeulebroecke, K., Hoste, B., Euras Vilalta, N., Rusul, G. \& Swings, J. (2002). Lactobacillus durianis sp. nov., isolated from an acid-fermented condiment (tempoyak) in Malaysia. Int J Syst Evol Microbiol 52, 927-931.

Lemos, M. L., Toranzo, A. E. \& Barja, J. L. (1985). Modified medium for oxidation-fermentation test in the identification of marine bacteria. Appl Environ Microbiol 40, 1541-1543.

Marmur, J. (1961). A procedure for the isolation of deoxyribonucleic acid from microorganisms. J Mol Biol 3, 208-218.

Marmur, J. \& Doty, P. (1962). Determination of the base composition of deoxyribonucleic acid from its thermal denaturation temperature. J Mol Biol 5, 109-118.
Mesbah, M., Premachandran, U. \& Whitman, W. B. (1989). Precise measurement of the $\mathrm{G}+\mathrm{C}$ content of deoxyribonucleic acid by highperformance liquid chromatography. Int J Syst Bacteriol 38, 159-167.

Nakagawa, Y. \& Yamasato, K. (1993). Phylogenetic diversity of the genus Cytophaga revealed by $16 \mathrm{~S}$ rRNA sequencing and menaquinone analysis. J Gen Microbiol 139, 1155-1161.

Nedashkovskaya, O. I., Suzuki, M., Vysotskii, M. V. \& Mikhailov, V. V. (2003). Reichenbachia agariperforans gen. nov., sp. nov., a novel marine bacterium in the phylum Cytophaga-FlavobacteriumBacteroides. Int J Syst Evol Microbiol 53, 81-85.

Pitcher, D. G., Saunders, N. A. \& Owen, R. J. (1989). Rapid extraction of bacterial genomic DNA with guanidium thiocyanate. Lett Appl Microbiol 8, 151-156.

Reichenbach, H. (1989). Genus I. Cytophaga Winogradsky 1929, $577,{ }^{\mathrm{AL}}$ emend. In Bergey's Manual of Systematic Bacteriology, vol. 3, pp. 2015-2050. Edited by J. T. Staley, M. P. Bryant, N. Pfennig \& J. C. Holt. Baltimore: Williams \& Wilkins.

Saitou, N. \& Nei, M. (1987). The neighbor-joining method: a new method for reconstructing phylogenetic trees. Mol Biol Evol 4 406-425.

Suzuki, M., Nakagawa, Y., Harayama, S. \& Yamamoto, S. (2001). Phylogenetic analysis and taxonomic study of marine Cytophaga-like bacteria: proposal for Tenacibaculum gen. nov. with Tenacibaculum maritimum comb. nov. and Tenacibaculum ovolyticum comb. nov., and description of Tenacibaculum mesophilum sp. nov. and Tenacibaculum amylolyticum sp. nov. Int J Syst Evol Microbiol 51, 1639-1652.

Thompson, J. D., Higgins, D. G. \& Gibson, T. J. (1994). CLUSTAL W: improving the sensitivity of progressive multiple sequence alignment through sequence weighting, position-specific gap penalties and weight matrix choice. Nucleic Acids Res 22, 4673-4680.

Van de Peer, Y., De Rijk, P., Wuyts, J., Winkelmans, T. \& De Wachter, R. (2000). The European small subunit ribosomal RNA database. Nucleic Acids Res 28, 175-176.

ZoBell, C. E. \& Upham, H. C. (1944). A list of marine bacteria including descriptions of sixty new species. Bull Scripps Inst Oceanogr Univ Calif 5, 239-292. 